Cornell Law Library

Scholarship@Cornell Law: A Digital Repository

Cornell Law Faculty Publications

Faculty Scholarship

1990

\title{
Democracy, Counterinsurgency, and Human Rights: The Case of Peru
}

\author{
Angela Cornell \\ Cornell Law School, abc49@cornell.edu
}

Kenneth Roberts

Follow this and additional works at: http://scholarship.law.cornell.edu/facpub

Part of the Foreign Law Commons, Human Rights Law Commons, Law and Society Commons, and the Politics Commons

\section{Recommended Citation}

Cornell, Angela and Roberts, Kenneth, "Democracy, Counterinsurgency, and Human Rights: The Case of Peru" (1990). Cornell Law Faculty Publications. Paper 980.

http://scholarship.law.cornell.edu/facpub/980

This Article is brought to you for free and open access by the Faculty Scholarship at Scholarship@Cornell Law: A Digital Repository. It has been accepted for inclusion in Cornell Law Faculty Publications by an authorized administrator of Scholarship@Cornell Law: A Digital Repository. For more information, please contact jmp8@cornell.edu. 


\title{
Democracy, Counterinsurgency, and Human Rights: The Case of Peru
}

\author{
Angela Cornell and Kenneth Roberts*
}

The wave of authoritarianism that swept over Latin America in the 1960s and 1970s focused international attention on the human rights violations committed by military dictatorships. As most Latin American nations experienced transitions to democratic rule in the 1980s, hopes were raised that human rights would be more widely respected. Nevertheless, it is questionable whether a regime change from dictatorship to democracy necessarily entails renewed respect for human rights. Does redemocratization represent a fundamental change in the exercise of political authority-that is, in relations between the state and civil society-or are there conditions under which democratic institutions and constitutional norms may fail to safeguard basic human rights?

In Brazil, Argentina, Uruguay, and Chile, human rights concerns under newly established democratic regimes have been dominated by the issue of military accountability for the abuses committed under previous authoritarian rule. Although these new democratic regimes have confronted serious obstacles to the prosecution of military officers for past human rights abuses, they have significantly improved the contemporary human rights conditions in their respective nations. In contrast, in Peru there has been a sharp upsurge in the level of human rights violations since the transition from authoritarian to democratic rule in 1980. These violations have been associated with a counterinsurgency campaign launched by the democratic regime against the revolutionary movement Sendero Luminoso (Shining Path), which initiated guerrilla operations in the midst of the regime transition in 1980.

* The authors would like to thank Joan Fitzpatrick and Susan Stokes for their assistance with this research, and Juan A. Mendez for his valuable comments on an earlier draft of the manuscript. Kenneth Roberts would also like to thank the John D. and Catherine T. MacArthur Foundation and the Center for International Security and Arms Control at Stanford University for their financial support of this research.

Human Rights Quarterly 12 (1990) 529-553 1990 by The Johns Hopkins University Press 
The Peruvian case demonstrates that human rights violations may continue to be a concern after the succession of democratic regimes. The legal and procedural norms associated with liberal democracy may be necessary conditions for the protection of human rights, but they clearly do not constitute sufficient conditions. As explained below, constitutional safeguards for human rights have been rendered inoperative in Peru, largely due to institutional failures and the abdication of civilian political, administrative, and juridical authority over the military and its counterinsurgency campaign. ${ }^{1}$ This abdication of civilian authority has enabled the armed forces to violate human rights with impunity and operate virtually unfettered by the legal and political constraints of constitutional norms and democratic accountability. Consequently, the counterinsurgency campaign has eroded the foundations of Peru's constitutional order, creating a state within a state where the military exercises de facto authority insulated from civilian institutions or political control. ${ }^{2}$

To place this case study of Peru within the broader, comparative context of Latin American politics, our analysis will begin with a brief discussion of the relationships between human rights, political regimes, and regime transitions. We will then proceed with an examination of the legal and institutional protections for human rights under Peru's democratic constitution and the mechanisms by which they have been rendered inoperable or ineffective. This analysis should demonstrate that the problem of human rights violations under democratic rule in Peru is not unique but is indicative of two, more general problems: the imposition of civilian control over the armed forces under new and frequently unstable democratic regimes, and the balancing of democratic norms with counterinsurgency tactics when guerrilla movements challenge state institutions.

\section{POLITICAL REGIMES AND HUMAN RIGHTS IN LATIN AMERICA}

It is hardly surprising that the regional trend toward democratization in the 1980 s spawned hopes for a renewed commitment to human rights in Latin America. Democratic transitions were understood to entail the restructuring of relations between the state and society, or between the rulers and the ruled. In place of political exclusion and repression, the norms of citizenship, participation, and representation were to prevail, making rulers accountable

1. Americas Watch, Abdicating Democratic Authority: Human Rights in Peru (New York: Oct. 1984).

2. Diego Garcia-Sayan, "Peru: Estados de Excepcion y Regimen Juridico," in Diego GarciaSayan, ed., Estados de Emergencia en la Region Andina (Lima: Comision Andina de Juristas, 1987), 117. 
to the public where they had previously been insulated. ${ }^{3}$ With its respect for individual autonomy and the equality of citizenship, liberal democracy was seen as a prerequisite for the existence of individual claims against the state, from which human rights were to flow. ${ }^{4}$

These norms of citizenship and political accountability stand in sharp contrast to the political practices of authoritarian regimes in Latin America. Studies of bureaucratic authoritarianism in the relatively developed societies of Latin America's Southern Cone (Brazil, Argentina, Uruguay, and Chile) have characterized the raison d'etre of military rule as the enforcement of the political and economic exclusion of previously mobilized popular sectors. ${ }^{5}$ Where these lower and middle class social and political movements utilized democratic liberties to challenge established social hierarchies, military institutions and economic elites redefined national security to guard against domestic (as opposed to external) threats to the status quo. Under the influence of an internally oriented, anti-subversive "national security doctrine, ${ }^{\prime 6}$ the armed forces toppled democratic regimes and used violence to suppress opposition political parties and social organizations, especially those on the political left. ${ }^{7}$ The record of human rights abuses associated with this political demobilization and repression hardly needs to be retold, with thousands of victims arbitrarily arrested, imprisoned, tortured, killed, or "disappeared."

These exclusionary military regimes systematically restricted or abolished the mediatory institutions that linked the state to civil society under democratic regimes and served as mechanisms of democratic accountability. Legislatures, political parties, and electoral processes were suppressed or restricted, while political controls were imposed on judicial institutions and the mass media. The repression and crippling of these countervailing institutions enabled the armed forces to centralize political authority and violate

3. See Guillermo A. O'Donnell and Philippe C. Schmitter, Transitions from Authoritarian Rule: Tentative Conclusions about Uncertain Democracies (Baltimore: Johns Hopkins University Press, 1986), especially on the linkage between democratization and citizenship.

4. For a theoretical exploration of the relationship between human rights and political regimes, see Rhoda E. Howard and Jack Donnelly, "Human Dignity, Human Rights, and Political Regimes," American Political Science Review 80, 3 (Sept. 1986): 801-17; for an empirical analysis, see Niel J. Mitchell and James M. McCormick, "Economic and Political Explanations of Human Rights Violations," World Politics 40, 4 (July 1988): 476-98.

5. The seminal work is Guillermo A. O'Donnell, Modernization and Bureaucratic-Authoritarianism (Berkeley: Institute of International Studies, 1973). A useful overview and critique is David Collier, ed., The New Authoritarianism in Latin America (Princeton: Princeton University Press, 1979).

6. The original work on the reorientation of military ideology to stress internal order and security is Alfred Stepan's "The New Professionalism of Internal Warfare and Military Role Expansion," in Alfred Stepan, ed., Authoritarian Brazil (New Haven: Yale University Press, 1973), 47-65.

7. A graphic example can be found in Karen L. Remmer, "Political Demobilization in Chile, 1973-1978," Comparative Politics 12, 3 (April 1980): 275-302. 
individual human rights without being encumbered by institutional checks and balances or operative legal constraints.

In the highly influential formulation of Guillermo $\mathrm{O}^{\prime}$ Donnell, the chasm that existed between the state and society under bureaucratic authoritarian rule could only be closed by the reconstruction of mediatory institutions and the restoration of mechanisms for governmental accountability - in short, by a process of redemocratization. ${ }^{8}$ But as military officers have withdrawn from the seats of government in Latin America and returned to the barracks, they have not necessarily relinquished political power. ${ }^{9}$ Indeed, the control of newly elected civilian authorities over the armed forces is likely to be highly tentative and contingent, depending upon the nature of the regime transition, the restrictions built into new democratic procedures, and the process of demilitarizing political power. As Alfred Stepan points out, the armed forces are likely to retain "prerogatives" under newly established democratic regimes that enable them to exercise decisional authority (or at least veto power) in a number of institutional and policy domains. ${ }^{10}$ The greater the number of military prerogatives, and the more prominent the institutional and policy domains in which they are maintained, the more constrained will be the political authority of civilian officials and institutions.

In the Peruvian case, the emergence of a guerrilla insurgency during a democratic transition exacerbated the problems of demilitarizing political authority and restricting military prerogatives. The rapid development of the Sendero Luminoso insurgency in the early 1980 s made the newly installed democratic regime dependent upon the armed forces for internal security, thus altering the balance of power between civilian and military institutions and undermining the authority of elected officials. It also created a policy domain - that of counterinsurgency - in which the military would inevitably wield considerable influence. Indeed, the democratic administration of President Fernando Belaúnde Terry, elected in 1980, not only granted the military tactical and operational control over the counterinsurgency campaign, it also ceded political and administrative authority to the armed forces in the zones of emergency that were declared in several departments of the Andean highlands where Sendero Luminoso was especially active.

This abdication of political authority, and the subsequent weakening of constitutional guarantees and democratic accountability, created the context for a wave of human rights abuses that surpassed anything Peru had experienced under its previous authoritarian regime. As such, the violence in

8. Guillermo A. O'Donnell, "Tensions in the Bureaucratic-Authoritarian State and the Question of Democracy," in Collier, note 5 above, 285-318.

9. See the epilogue in Alain Rouquie, The Military and the State in Latin America (Berkeley: University of California Press, 1987), 385-405.

10. Alfred Stepan, Rethinking Military Politics (Princeton: Princeton University Press, 1988), 93-127. 
Peru provides a graphic demonstration of the societal and political conditions under which constitutional principles and an ostensibly democratic regime may fail to ensure respect for fundamental human rights. But to properly understand this case, it is necessary to take a step backwards and trace the course of developments which plunged Peru into crisis in the 1980 s.

\section{THE STRUCTURAL ROOTS OF INSURGENCY}

Although Peru's recent political history has points in common with other Latin American nations, it diverges in several crucial respects. Like most of Latin America, Peru was under military rule between 1968 and 1980. However, unlike the military dictatorships in the Southern Cone and Central America, Peru's military government was committed to redistributive social and economic reforms, especially during its first phase under General Juan Velasco Alvarado from 1968 to $1975 .{ }^{11}$ Rather than repress and demobilize the popular sectors, the Velasco regime encouraged their organization and mobilization, and made efforts (ultimately unsuccessful) to incorporate them into national political processes, albeit in a manner which retained hierarchial corporatist and clientelist controls. ${ }^{12}$ However, under the constraints of a deteriorating economy, General Francisco Morales Bermúdez deposed the Velasco government in 1975 and instituted drastic austerity measures that caused widespread popular unrest. As popular opposition and labor strikes surged in 1977-78, the military first met the resistance with repression and then opted to withdraw from governance, arranging for the election of a constituent assembly in 1978 and a civilian president and congress in 1980.

Consequently, the new democratic leaders replaced a military regime whose human rights record, although far from unblemished, was hardly as notorious as those in Central America or the Southern Cone. In contrast to the pattern in the Southern Cone, human rights emerged as a major theme in Peruvian politics due to the surge in violations committed by the armed forces after the succession of the democratic regime. This anomaly is attributable not only to the unusual populist characteristics of the Peruvian military regime but also to the lack of a counterinsurgency campaign under

11. For an overview see Cynthia McClintock and Abraham F. Lowenthal, eds., The Peruvian Experiment Reconsidered (Princeton: Princeton University Press, 1983); see also Stephen M. Gorman, ed., Post-Revolutionary Peru: The Politics of Transformation (Boulder, Colo.: Westview Press, 1982).

12. The relationship between the authoritarian regime and popular organizations is analyzed in Alfred Stepan, The State and Society: Peru in Comparative Perspective (Princeton: Princeton University Press, 1978); see also Evelyne Huber Stephens, "The Peruvian Military Government, Labor Mobilization, and the Political Strength of the Left," Latin American Research Review 18, 2 (1983): 57-93. 
the military government, since Sendero Luminoso did not initiate guerrilla operations until the democratic transition was underway. ${ }^{13}$

Throughout the 1980s, the intensity of human rights violations in Peru closely paralleled the spiral of insurgency and counterinsurgency. The brunt of the violence has been borne by the indigenous Indian communities in the southern Andean highlands, particularly in the department of Ayacucho, the birthplace and original center of operations for Sendero Luminoso. The departments of the southern highlands are among the most isolated and economically underdeveloped in Peru, with widespread poverty and a significant number of persons who speak only the indigenous language, Quechua, rather than Spanish.

As of the early 1970s, life expectancy at birth in the southern highlands was only forty-four years (compared to fifty-seven years in Lima), and adult illiteracy was 53 percent (compared to 6 percent in Lima). Although a predominantly agricultural area, it has been estimated that the average per capita caloric intake in the southern highlands in the early 1980 s was less than 70 percent of the daily minimum requirement established by the Food and Agricultural Organization of the United Nations. Similarly, when Sendero Luminoso began its insurgency, annual per capita farm incomes for this region were estimated at less than $\$ 50$, far less than per capita incomes in the central and northern highlands, the coastal region, or the capital city of Lima. ${ }^{14}$

This severely impoverished region proved to be fertile ground for the doctrinaire and messianic version of Maoism preached by Sendero Luminoso, which was born in the provincial University of Huamanga (Ayacucho) in the 1960s under the leadership of philosophy professor Abimael Guzmán Reynoso. ${ }^{15}$ In an atmosphere of economic deprivation, latent cultural resentment of Hispanic domination, and generalized despair for the future, Sendero attracted a committed following, especially among the indigenous youth who had attained access to higher education. ${ }^{16}$ With its activists having spent years living, working, and teaching in the highland communities prior

13. Indeed, the Sendero insurgency began with the burning of ballot boxes in the town of Chuschi in the department of Ayacucho on the day of Peru's national elections in May 1980.

14. These figures are obtained from Cynthia McClintock, "Why Peasants Rebel: The Case of Peru's Sendero Luminoso," World Politics 37, 1 (Oct. 1984): 59-61.

15. On the origins and early development of Sendero Luminoso in Ayacucho, see Carlos Ivan Degregori, Ayacucho 1969-1979: El Surgimiento de Sendero Luminoso (Lima: Instituto de Estudios Peruanos, 1990).

16. In "Why Peasants Rebel," McClintock attributes the rebellion to a subsistence crisis and the politicizing effects of the failed socioeconomic reforms of the military government. The insurgency has also been characterized as a rebellion of the economic and cultural "periphery" against the dominant "center"; see David Scott Palmer, "Rebellion in Rural Peru: The Origins and Evolution of Sendero Luminoso," Comparative Politics 18, 2 (Jan. 1986): $127-46$. 
to the initiation of armed struggle, Sendero had carefully cultivated a regional social base for rural guerrilla insurgency.

The deep cultural and ethnic cleavages between the Hispanic and indigenous populations not only helped spawn the insurgency, but also compounded the human rights problems attendant to the government's counterinsurgency campaign. Many indigenous communities are suspicious of the military and the national government in Lima, given the legacy of five centuries of Hispanic domination. Likewise, the predominantly Hispanic and mestizo (mixed race) armed forces feel as if they are on alien territory within the indigenous communities and are suspicious of the political loyalties of the Indian population. This political distrust, combined with deeply ingrained racial prejudices against the indigenous population, have unquestionably escalated the level of violence associated with counterinsurgency.

\section{COUNTERINSURGENCY AND THE VIOLATION OF HUMAN RIGHTS}

When Sendero Luminoso initiated armed struggle in May 1980, few considered it a serious threat to the new democratic order. However, the guerrilla movement rapidly expanded its operations in Ayacucho, dynamiting public buildings and power stations and summarily executing local officials, landowners, merchants, and informers after staging "popular trials." Responding to the guerrilla offensive in March 1981, the newly elected Belaúnde government passed Legislative Decree 46, a sweeping anti-terrorist law which established strict penalties for persons convicted of terrorism and enabled the police to detain suspects for up to fifteen days without court interference. ${ }^{17}$ This law permitted the government to arrest and imprison hundreds of suspected members and sympathizers of Sendero Luminoso. However, the broad definition of terrorism contained in the law and the scope of its application resulted in the detention of many innocent activists in student, labor, peasant, and community organizations. By November 1983, 2,294 persons had been detained, most of them in accordance with the new anti-terrorist legislation. ${ }^{18}$

The human rights situation deteriorated further after December 1982, when the national government declared a state of emergency in four provinces of the department of Ayacucho. These provinces and their civilian governments were placed under the administrative control of political-military commands that were headed by military officers appointed by the president. The armed forces also stepped up the counterinsurgency campaign

17. Legislative Decree 46, see Americas Watch, note 1 above, 32.

18. Ibid., 34. 
in the southern highlands, particularly in the departments of Ayacucho, Apurimac, and Huancavelica. These acts resulted in a surge of allegations that the military was systematically using torture, disappearances, and extrajudicial executions to pacify the indigenous communities and suppress Sendero Luminoso activities. By December 1983, the attorney general acknowledged that his office had received 1,200 allegations of disappearances. ${ }^{19}$

Military sweeps through the countryside also resulted in mass executions of civilian noncombatants. This scorched-earth approach to counterinsurgency was manifested in a December 1982 statement by the Minister of War, General Luís Cisneros: "We are professional soldiers and we are trained to kill. . . . [T]o be successful [in Ayacucho] we have to begin to kill Senderistas and civilians. ... We may kill 60 people, and at best, there are 3 Senderistas among them . . . and the police will say that all 60 were 'Senderistas.' "'20

The excessive violence of the government's counterinsurgency campaign, combined with a severe economic recession in 1982-1983, undermined the popularity of the Belaúnde administration. However, hopes for change were raised by the 1985 election of a young, charismatic president, Alan García Perez. Running on the reformist platform of the American Popular Revolutionary Alliance (APRA), García pledged to respect human rights and restore economic growth with a heterodox recovery plan. Claiming that the guerrilla insurgency could be combatted more effectively with social and economic measures than political repression, García promised in his inaugural address that "the use of death as a means to an end is unacceptable under a democratic system. . . . The law will be strictly applied to those who violate human rights by assassinations, extrajudicial executions and torture. . . It is not necessary to fall into barbarism to fight barbarism. ${ }^{\prime 21}$

García's efforts resulted in a temporary improvement in the human rights situation and in the economy as well. The army's counterinsurgency tactics had weakened the Sendero Luminoso stronghold in Ayacucho, and the number of disappearances and extrajudicial killings by the armed forces declined after García became president. An average of about 600 disappearances were reported annually during the final two and a half years of the Belaúnde administration, while reports fell to an average of about 100 a year during the first two and a half years under García. ${ }^{22}$ When mass graves were discovered in the villages of Accomarca and Pucayacu shortly

19. Ibid., 102.

20. Ibid., 87.

21. Quoted in the Special Report of the Washington Office on Latin America, Peru in Peril: The Economy and Human Rights, 1985-1987 (Washington, D.C.: Nov. 1987), 23.

22. Americas Watch, Tolerating Abuses: Violations of Human Rights in Peru (New York: Oct. 1988), 39. 
after García took office, the president ordered an investigation and dismissed the chairman of the armed forces joint chiefs of staff.

Over time, however, García's capacity - and willingness - to control the armed forces and protect human rights came into question. In June 1986, a simultaneous uprising involving Sendero inmates occurred in three prisons in the Lima area. The prisoners took hostages and demanded improvements in living conditions, accelerated judicial proceedings, and an end to the harassment of their families and lawyers. ${ }^{23}$ García declared a state of emergency in the areas surrounding the prisons and ordered the armed forces to suppress the uprising. An estimated 300 prisoners were killed, including ninety in one prison who were shot at close range after surrendering. ${ }^{24}$

Meanwhile, Sendero Luminoso responded to the counterinsurgency campaign in the southern highlands by dispersing its forces throughout the country. Sendero activities expanded into the upper Huallaga Valley - the heart of Peru's cocaine-producing territory-as well as the central and northern Andean highlands and the capital of Lima, where sprawling shantytown settlements provided new bases for recruitment. The insurgency problem was compounded by the emergence of a second leftist guerrilla movement in the mid-1980s, Movimiento Revolucionario Tupac Amaru, named for an eighteenth century Inca leader who led a rebellion against Spanish domination. The descent into chaos was accelerated by the deterioration of the Peruvian economy after mid-1987. Garcia's heterodox program produced two years of rapid economic growth but in the process engendered a foreignexchange bottleneck and uncontrollable inflationary pressures. The onset of hyperinflation in 1988 led to a series of economic adjustment or "shock" plans which plunged Peru into the most severe depression in the nation's modern history. By March 1989, the gross domestic product had fallen by 24.5 percent compared to its level only one year earlier, and inflation had surged to an annual rate of over 2,500 percent. ${ }^{25}$

As García's economic program lost is reformist impulse and became increasingly erratic, his early efforts to protect human rights also yielded to counterinsurgency objectives. In July 1988 , the president proposed new antiterrorist legislation and the repeal of Law 24,700, which had provided detainees with safeguards during criminal investigations. The new legislation was designed to redefine the offense of terrorism by making it possible to prosecute individuals for belonging to a guerrilla movement, possessing arms or explosives, or expressing sympathy for a group that advocates the use of violence. In short, the new legislation allowed conviction for terrorism without the commission of violent actions; it defined terrorism very broadly and

23. Washington Office on Latin America, note 21 above, 33.

24. Americas Watch, note 22 above, 63.

25. For a description of the economic crisis, see "Peru in the Throes of Deep Recession," Latin American Regional Reports: Andean Group, 27 July 1989, 4-5. 
ambiguously as any act committed with the intention of altering or destabilizing the constitutional system or affecting the security of the state. ${ }^{26}$

García's effort to repeal Law 24,700 also threatened to erode existing protection for detainees under investigation, particularly by giving investigative powers to the police rather than public prosecutors. This law had been designed to ensure that detainees had medical attention and legal counsel and that public prosecutors, not the police, would be in charge of investigations "in order to defend legality, human rights, and the interests protected by law." ${ }^{\prime 27}$ These restrictions on the investigative activities of the police had sparked criticism from a number of government and law enforcement officials, including the director of the Peruvian investigative police, whose units have been widely accused of extracting confessions through the use of torture. ${ }^{28}$ Indeed, a poll conducted by the Institute for Legal Defense, a Peruvian nongovernmental human rights organization, revealed that among defendants who claimed not to be members of any armed organization, more than 90 percent had been mistreated at the initial stages of investigation, did not have a lawyer at the time of their first interrogation, and had not been provided with a free, court-appointed lawyer as required by Peruvian law. ${ }^{29}$

As the legal norms protecting human rights were being emasculated, a new and perhaps even more ominous threat appeared in the summer of 1988: a right-wing paramilitary death squad known as the Comando Rodrigo Franco (CRF). Named for an APRA leader who was slain by Sendero Luminoso in 1987, the Comando broke into public view with the assassination of Manuel Febres, a prominent lawyer with the Association of Democratic Lawyers. At the time of his murder, Febres was defending Oscar Morote, who was standing trial as the reputed second-in-command of Sendero Luminoso. In subsequent months, the Comando engaged in a number of additional assassinations and bombings, while sending death threats to lawyers, public prosecutors, human rights workers, union officials, and members of congress.

The expansion of right-wing paramilitary activities, and widespread allegations linking such activities to APRA and members of state security forces, led to the formation of a special parliamentary investigative commission in May $1989 .^{30}$ This commission faced a number of obstacles, including political pressure from the Ministry of Interior and, according to non-APRA

26. Americas Watch, note 22 above, 31 .

27. Ibid., 28.

28. See Inter-Church Committee on Human Rights in Latin America, "ICCHRLA's Annual Reports on Human Rights in Latin America," ICCHRLA Newsletter 1-2 (1989), 55.

29. This poll is cited in Americas Watch, note 22 above, 29.

30. The creation of this commission was precipitated by the assassination of two congressmen, including deputy Eriberto Arroyo Mio of the opposition Izquierda Unida (United Left), whose death was attributed to the Comando Rodrigo Franco. 
members of the commission, efforts by the APRA majority to cover up information and prematurely close the investigation. Two commission members from the opposition Izquierda Unida (United Left) received death threats, and one had his daughter kidnapped and threatened.

Despite these impediments, in October 1989, the non-APRA members of the commission issued a minority report based upon the testimony of alleged former members of the CRF and other documentation linking death squad activities directly to APRA's Interior Minister, Augustin Mantilla, and top generals of the national police. ${ }^{31}$ According to Amnesty International, paramilitary activities attributed to the CRF are conducted by different government security forces, depending upon the locale; military forces are the principal culprits in zones of emergency, and personnel from the national police or APRA are responsible in other areas. Thus, the CRF "is not a lone independent 'death squad,' " but rather "a masquerade, a methodology to obscure responsibility for the elimination of government opponents." ${ }^{\prime 32}$

By early 1989, mired in a downward spiral of political violence and economic decay, Peru's democratic system teetered on the brink of a complete breakdown as rumors of a possible military coup shook the nation. Killings and disappearances attributed to the armed forces continued to occur in the southern highlands and other emergency zones, and although the absolute numbers remained below the extremely high levels of 1983-1984, they rose sharply above the figures for the first two years of García's tenure. According to the UN Working Group on Enforced or Involuntary Disappearances, ${ }^{33}$ Peru had the dubious distinction of being the nation with the highest reported number of new cases of disappearances for the years 1987 (seventy-nine) and 1988 (170). The number more than doubled again in 1989, with 404 new cases being reported by the United Nations. ${ }^{34}$

As the number of enforced disappearances increased sharply in 1988 and 1989 , so did the geographical scope of the practice, reflecting the extension of counterinsurgency practices to new areas in response to the expansion of the guerrilla operations of Sendero Luminoso. According to Amnesty International, disappearances before 1988 were restricted solely to areas under military control due to states of emergency, with the Ayacucho emergency zone accounting for the bulk of the cases. In 1988, however,

31. For an overview of death squad activities and the parliamentary investigative commission, see Instituto de Defensa Legal, Peru 1989: En la Espiral de Violencia (Lima: 1990), 15571.

32. Amnesty International, Caught Between Two Fires: Peru Briefing (New York: Nov. 1989), 13.

33. See Report of the United Nations Working Group on Enforced or Involuntary Disappearances, U.N. Doc. E/CN.4/1988/19 at 49 (1988) and U.N. Doc. E/CN.4/1989/18 at 61-64 (1989); see also Americas Watch, note 22 above, 41.

34. Report of the United Nations Working Group on Enforced or Involuntary Disappearances, U.N. Doc. E/CN.4/1990/13 at 59. 
disappearances were reported for the first time in areas that were not under states of emergency. ${ }^{35}$ Disappearances were reported in six departments and the municipal province of Lima, and in 1989, reports were recorded from eleven departments, with Apurimac replacing Ayacucho as the department with the highest incidence of reported disappearances. ${ }^{36}$ Indeed, by 1989 eight complete departments and Lima were under states of emergency, accounting for more than half the national population.

Overall, the Office of the Attorney General of Peru recorded over 3,200 cases of enforced disappearances reported between 1982 and August 1989. ${ }^{37}$ The actual number is probably much higher, however, since many cases are not reported due to the fear of harassment or reprisals against lawyers, human rights organizations, witnesses, and family members who pursue cases of disappearances. Additionally, the Peruvian Senate's special investigative commission on terrorism and violence reported in January 1990 that 15,811 persons were killed in political violence in Peru during the 1980s, including 1,197 members of the armed forces, 8,079 alleged "subversives," and 6,386 civilians. ${ }^{38}$ Evidence gathered by human rights organizations demonstrates that civilians are trapped between the violent practices of the armed forces and those of an insurgent organization renowned for its own brutality: for example, Sendero Luminoso was responsible for 1,298 political assassinations in 1989 alone, with an additional 1,438 persons killed in armed conflict with the military, including 255 members of the armed forces and 1,116 "subversive agents" of unknown status. ${ }^{39}$

To compound this situation of political violence, Americas Watch reports that torture is practiced "habitually" in police interrogations and that public officials took no steps to curb this practice under the administration of President García. ${ }^{40}$ Additionally, the final two years of García's term witnessed a growing tendency toward state repression against social organizations and popular mobilization. For example, in February 1989 police forces in the city of Pucallpa opened fire upon peasants who were holding a march to celebrate the negotiated resolution of an agricultural strike, resulting in at least eight deaths and dozens of injuries, along with some 300 detentions. ${ }^{41}$ Military incursions have also occurred in universities and

35. Amnesty International, Peru: Human Rights in a State of Emergency (London: Aug. 1989), 1.

36. This information was obtained from the statistical files of the Center for Documentation at the Asociacion Pro Derechos Humanos (APRODEH) in Lima.

37. Inter-Church Committee on Human Rights in Latin America, 1989 Annual Report on the Human Rights Situation in Peru (Toronto: Jan. 1990), 19.

38. Comision Especial de Estudio y Investigacion Sobre Terrorismo y Otras Manifestaciones de la Violencia, La Violencia en el Peru: Informe 1989 (Lima: Jan. 1990), 23. The Commission reported that this figure is undoubtedly conservative due to information loss and data scarcity, and estimates that the true figure is probably closer to 17,500 .

39. National Human Rights Coordinating Committee, Boletin Informativo 5 (Nov. 1989-Jan. 1990), 4.

40. Americas Watch, note 22 above, 44 .

41. Instituto de Defensa Legal, note 31 above, 177-83. 
mining camps, resulting in massive detentions and the selective assassination of union leaders from the Federation of Miners. Police forces have routinely used buckshot to break up demonstrations by striking workers, leading to frequent injuries. ${ }^{42}$

Finally, individuals and organizations who defend human rights have also come under increasing attack. A wave of threats and attacks took place in early 1990, including a grenade attack on the headquarters of the Andean Commission of Jurists, the bombing of the local office of Amnesty International, the detention and disappearance of a human rights director in Huancavelica, and death threats from the Comando Rodrigo Franco against the coordinator of the Association for Human Rights (APRODEH). These attacks led Americas Watch and the National Human Rights Coordinating Committee to issue denunciations of the actions and appeals to Peru's presidential candidates to speak out on behalf of human rights. ${ }^{43}$

As this brief overview suggests, the democratic regime in Peru-under both the Belaúnde and García administrations - has not only failed to defend civilians from the violent attacks of Sendero Luminoso but has acquired a record of human rights violations that rivals those of the notorious military regimes that recently ruled in the Southern Cone and Central America. The legal and constitutional norms crafted to defend human rights in Peru have been breached as political and military leaders have given precedence to counterinsurgency objectives. But what, precisely, are those legal norms, and to what causes do we attribute their breakdown under a democratic regime in Peru? As explained below, the most important factors have been the suspension of basic rights and the abdication of civilian authority under states of emergency, the impotence of the judicial system, and the inability or unwillingness of civilian authorities to hold military personnel accountable for abuses of power. These political and institutional failures have allowed the counterinsurgency campaign to be conducted with impunity, in disregard for fundamental human rights standards and safeguards.

\section{THE CONSTITUTIONAL FRAMEWORK: SAFEGUARDS AND EXCEPTIONS}

The Peruvian Constitution was drafted by a popularly elected constituent assembly and took effect as the nation returned to democratic rule in July 1980. Following twelve years of military government, the writers of the new

42. Indeed, this practice has even resulted in injuries to prominent opposition political leaders, including Senator Javier Diez Canseco and former presidential candidate Henry Pease, both of the United Left, who were participating in workers' marches.

43. See Americas Watch, Wave of Violence Against Peru's Human Rights Community, 18 March 1990; see also Coordinadora Nacional de Derechos Humanos, Boletin Informativo 6 (Feb. 1990), 4. 
constitution were especially anxious to create a legal foundation to protect human rights. As such, the constitution lists a full panoply of individual civil and political rights relating to personal freedom and security: the right to habeas corpus; the right not to be convicted under ex post facto laws; the right to be presumed innocent until proven guilty in judicial proceedings; the right not to be arrested except pursuant to a judicial warrant or during the commission of an offense; the right to be brought before a judge within twenty-four hours of arrest (with exceptions for crimes involving terrorism, espionage, and unlawful drug trafficking); the right to be informed immediately and in writing of the reason for detention; the right to communicate with an attorney from the time of arrest; the duty of authorities to report the location of the detainee; the inadmissibility of forced statements; the right not to be held in incommunicado detention; the right not be transferred to a jurisdiction not provided for by law; and the right not to be tried under procedures other than those established by law. ${ }^{44}$

Additionally, the constitution prohibits the practice of torture or inhumane treatment and abolishes the death penalty except for treason during foreign war, an exception that does not encompass a domestic state of emergency. ${ }^{45}$ Civilians also cannot be subjected to military jurisdiction except for the case of high treason during foreign war. ${ }^{46}$

Finally, constitutional priority is given to human rights principles contained in international treaties signed by the Peruvian government, which include the International Covenant on Civil and Political Rights, the Optional Protocol to that treaty, and the American Convention on Human Rights. ${ }^{47}$ These accords state that governments have the right to derogate certain treaty obligations in times of public emergency. However, derogations are to be strictly proportional to the exigencies of the situation, and certain nonderogable rights are to be preserved, including the rights to life, juridical personality, and humane treatment.

Although international law recognizes the right of governments to establish states of exception that derogate certain rights during periods of emergency, there are a number of problems with such states of exception, and they can easily erode the safeguards that are designed to ensure respect for human rights. First, the definition of a national emergency allows for a number of different interpretations; political leaders may conceive of any challenge to their personal or governmental authority as a threat to the public interest or national security. Second, there is a danger that states of emergency will cease to be "exceptional"; that is, they may become the norm, leading to a semi-permanent breach of constitutional rights. Colombia, for example,

44. Peru Const., title l, chap. 1 , art. $2 \S 20$.

45. Ibid., at title IV, chap. IX, art. 234-35.

46. Ibid., at chap. XIII, art. 282.

47. Ibid., at title VIII, prov. XVI. 
has been in a state of siege for more than thirty years. ${ }^{48}$ Finally, even when states of emergency ostensibly accommodate nonderogable rights, there is the danger that emergency measures will weaken or obscure institutional controls, legal norms, and mechanisms of accountability that serve to protect citizens from abuses of authority. As such, states of emergency can create a political climate which is highly conducive to human rights violations.

The Peruvian case provides an example of these dangers. Article 231 of the Peruvian Constitution allows for the suspension of some civil and political rights under two different states of exception: the state of emergency and the state of siege. The president is empowered to decree both states of exception unilaterally, upon notification of the congress.

The state of emergency is the milder of the two forms of exception. It may be declared in all or part of the country to deal with a variety of disasters, disturbances of the peace or public order, or "grave circumstances affecting the life of the nation." Under a state of emergency, two "positive" constitutional freedoms (of movement and assembly) and two "negative" freedoms (from arbitrary arrest and unwarranted searches and seizures) are suspended. Other constitutional protections, including habeas corpus, are to remain operable. A state of emergency is valid for sixty days but can be renewed by executive order as many times as necessary. Section 231(a) also allows the president to order the armed forces to assume responsibility for the maintenance of public order. ${ }^{49}$ This provision has been utilized in every emergency zone in Peru except Lima, thus placing these zones under the political authority of a military-controlled political-military command.

Neither the Belaúnde nor García administrations resorted to the declaration of a state of siege, which is the stronger of the two forms of exception. The state of siege has greater breadth because it suspends all personal guarantees that are not specifically retained. Nevertheless, even the milder states of emergency declared in eight departments and Lima have been sufficient to seriously erode constitutional safeguards. The states of emergency have formally suspended some individual rights and protections while vesting political and administrative authority in the hands of military officers who have not been held accountable to civilian institutions or to the remaining legal and constitutional norms. States of exception have enabled the armed forces to act with impunity in their counterinsurgency campaign in the southern highlands, control labor unrest, and launch police round-ups of suspected criminals or opposition activists. For example, during a state of emergency in July 1984, police and military forces detained as many as 19,000 people in what was putatively an anti-terrorist operation. In the words

48. See Guillermo Figallo, "Presentacion," in Garcia Sayan, ed., note 2 above, 14.

49. International Commission of Jurists, States of Emergency: Their Impact on Human Rights (Geneva: 1983), 272-73. 
of Americas Watch, "such sweeps generally result in indiscriminate victimization of the poor who have limited means to protect themselves from abuse by local police officials. ${ }^{\prime 50}$

Furthermore, the states of emergency have undermined the judicial system, which has long been noted for its impotence, corruption, and lack of political autonomy. ${ }^{51}$ Since the ceding of civilian authority to politicalmilitary commands in 1982, civilian courts in emergency zones have been denied access to detention facilities, thereby making it impossible for them to pursue writs of habeas corpus. Lawyers who defend detainees also fear that they will be labeled as terrorists by the military, especially in the emergency zones. ${ }^{52}$ This fear is not unfounded, given the harassment, threats, and attacks suffered by lawyers and other human rights activists.

Indeed, the lack of public confidence in the integrity and efficacy of the judiciary system is manifested by the minuscule number of habeas corpus writs that have been filed in Peru, relative to the number of detainees and disappeared persons. For example, during the height of the counterinsurgency campaign in Ayacucho in 1983-1984, only fourteen writs of habeas corpus were filed, even though the attorney general admitted publicly that there were over 2,000 denunciations of detentions or disappearances. ${ }^{53}$

This is especially disturbing, considering that the Peruvian Constitution established streamlined procedures to facilitate recourse to this domestic remedy for human rights abuses. A writ of habeas corpus can be filed when an act or omission by any authority or official threatens individual liberty. Habeas corpus proceedings need not be instituted by the injured party; any person acting on behalf of the injured party can bring the action with no need for the power of attorney or a lawyer's signature. Habeas corpus can even be instituted orally or by telegram. That so few writs are filed, and that they are routinely denied, attests to the ineffectiveness of one of the principal domestic remedies available to citizens under the Peruvian Constitution.

If the judicial system has proven inadequate to the task of protecting individuals from police and military abuses, it has been even less successful in holding the armed forces accountable for their actions and imposing sanctions for abuses of power. As shown below, the armed forces have been able to violate human rights with impunity, confident that there is little or no possibility that they will be prosecuted or punished for their actions.

50. Americas Watch, note 1 above, 31.

51. See the presentation by Diego Garcia-Sayan included in "Para Asegurar la Vigencia de los Derechos Humanos," in Julio Cotler, ed., Para Afirmar la Democracia (Lima: Instituto de Estudios Peruanos, 1987).

52. Report of the Working Group on Enforced or Involuntary Disappearances, U.N. Doc. E/ CN.4/1986/18/Add. 1 at 17 (1986).

53. Garcia-Sayan, note 51 above, 131. 


\section{HUMAN RIGHTS AND MILITARY ACCOUNTABILITY}

In Latin American nations that have undergone recent transitions from authoritarian to democratic regimes, perhaps no other issue has been as sensitive and contentious as accountability for human rights violations committed under military rule. In Brazil, Uruguay, Guatemala, and El Salvador, civilian governments with a tenuous hold on political power cautiously backed away from efforts to prosecute military officers for human rights violations. In Argentina, where the armed forces were seriously discredited by the debacle of the Falklands/Malvinas War, the democratic regime of Raúl Alfonsín successfully prosecuted military officers for human rights violations. This seriously strained relations between the armed forces and civilian authorities, however, and the administration of Carlos Menem subsequently pardoned most of the senior officers who had been convicted or who faced charges.

The situation is considerably different in Peru, since the most egregious human rights violations have occurred under a democratic regime that is still in power, rather than a military government that has left office. Nevertheless, the outcome has been similar to that in most of Latin America; little progress has been made in bringing military officers to trial or imposing legal sanctions.

Under Article $\mathbf{2 8 2}$ of the Peruvian Constitution, members of the armed forces and police who commit offenses are subject to the "appropriate jurisdiction" and the Code of Military Justice, which specifies the crimes appropriate for military jurisdiction. The constitution stipulates that military jurisdiction is to prevail only in cases where both the victim and the defendant are members of the armed forces; where the victim is a civilian, the civilian courts have jurisdiction. However, in practice there has been little effective civilian jurisdiction, especially since the passage of Law 24,150 in June 1985.

This law was designed to consolidate the control of the political-military commands in the emergency zones and bolster military jurisdiction over crimes committed by police and military personnel. Besides placing the political-military commands in charge of security forces and administrative agencies, the new law stipulated that crimes committed by security forces in the line of duty would be within the jurisdiction of the military courts unless the crimes had no relation to military service. ${ }^{54}$ The constitutionality of this law has been challenged by many Peruvian jurists and legislators, because it delegates considerable power to the armed forces and interferes

54. Amnesty International, Peru: Violations of Human Rights in the Emergency Zones (London: Aug. 1988), 17-18. 
with the authority of elected civilian officials. Several bills have been introduced before congress to repeal Law 24,150 and reestablish civilian control, including one proposal to appoint a cabinet-level official to administer the emergency zones. These bills have been blocked in congress, however, leaving military authority intact in the emergency zones. ${ }^{55}$

Since violations of human rights are considered to fall within the line of duty, the Peruvian Supreme Court of Justice-which decides whether military or civilian courts should rule on a case-has determined that these violations are to be prosecuted in military tribunals. The violations are treated jurisdictionally as military offenses, even though the victims are civilians and the constitution grants authority to civilian courts. Consequently, military courts have asserted jurisdiction over the vast majority of cases involving torture, disappearances, and mass executions. Furthermore, since Peru's Military Code of Justice does not include murder or torture as military offenses, those accused of such violations can only be convicted of negligence or abuse of authority, which generally carry minor sentences. ${ }^{56}$ Finally, under Article 19(7) of the Military Code of Justice, police and military personnel are not subject to criminal liability for the commission of acts ordered by a superior, so long as the order "is not notoriously illicit."

These legal loopholes have created de facto immunity for members of the armed forces who violate human rights and have considerably enhanced the military's autonomy from civilian control. According to Americas Watch, "The jurisdiction of military courts has become little more than an excuse for total impunity for members of military forces." ${ }^{\prime 58}$ Although there have been thousands of disappearances and extrajudicial executions reported since 1980, not a single member of the Peruvian armed forces has been convicted of human rights violations. Several police officers have been convicted of abuses in well-publicized cases, but only rarely has the Supreme Court of Justice ruled that a member of the police force should be tried by a civilian court.

In one precedent-setting case involving a long jurisdictional battle, twelve members of the Sinchis (special counterinsurgency police forces) were tried in civilian courts for the massacre of forty-two Indian peasants who were attending a wedding ceremony in the village of Soccos in 1983. This case was initially dismissed by an investigative judge for lack of evidence, but that decision was reversed on appeal. As proceedings resumed before the Ayacucho Superior Court, a key witness received death threats

55. Americas Watch, note 22 above, 26.

56. See Washington Office on Latin America, note 21 above, 31. Since the Military Code of Justice does not contemplate the offenses of murder and torture, human rights lawyers have argued that such crimes should properly be tried under civilian jurisdiction.

57. Amnesty International, note 54 above, 18.

58. Americas Watch, note 22 above, 81 . 
and a bomb exploded in the Palace of Justice. Despite these intimidation tactics, the defendants were convicted and sentenced to ten to twenty-five years in prison. ${ }^{59}$ This verdict was upheld by the Supreme Court of Justice in October 1987.

In contrast, where military (not police) forces are involved, the Supreme Court of Justice has generally upheld military jurisdiction, even for offenses that could not have occurred in the line of duty. This judicial abdication underscores the lack of political autonomy of the judiciary and its failure to play a stronger role in the defense of constitutional rights. For example, just one month after President García took office, a mass grave was discovered in the village of Accomarca, where sixty-nine persons had been massacred by the armed forces. Although García's early popularity and his pledge to hold the armed forces accountable for human rights violations created a political context that was conducive to judicial assertiveness, the supreme court ruled that a military tribunal had jurisdiction over the case under Law 24,150 . The military court refused to sanction any members of the armed forces for this massacre; in fact, an army second lieutenant was acquitted by a military court and then promoted by the army ${ }^{60}$

Likewise, the supreme court ruled in favor of military jurisdiction in a similar case at Pucayacu, where a mass grave containing fifty bodies was found, including several persons who had been in the custody of Naval Captain Alvaro Artaza Adrianzén. In its decision of 10 April 1985, the supreme court broadened the range of offenses that are considered to fall under the category of official duty and are thus subject to military jurisdiction. According to the court:

Offenses committed on official duty are not confined simply to offenses which concern or affect the exercise of the function discharged by the serviceman, but also cover all those which have a bearing or an effect on the functions or activities of every serviceman by the very fact that he belongs to the armed forces, since a nexus of causality between the offence committed and the function is not required: incidental occurrence is sufficient. ${ }^{61}$

Indeed, the only case of human rights violations by the military in which the supreme court has ruled in favor of civilian jurisdiction involved the disappearance of journalist Jaime Ayala Sulca. On 2 August 1984, Ayala, a journalist for the Lima newspaper La República, entered the marine barracks in Huanta, in the department of Ayacucho. Ayala was investigating the discovery of a clandestine grave which contained the bodies of six religious activists from Calqui, and he had scheduled an appointment to interview

59. Washington Office on Latin America, note 21 above, 30.

60. Ibid., 31 .

61. U.N. Doc. E/CN.4/1986/18/Add.1, note 52 above, 26. 
the commander of the marine infantry forces. Ayala was never seen again, and the publicity surrounding his disappearance prompted the initiation of judicial action against the commander of the marine base, Captain Artaza.

In 1986 the supreme court awarded jurisdiction in the case to civilian courts, and Artaza was charged with the disappearance of Jaime Ayala, the killing of the six religious activists from Calqui, and crimes relating to the discovery of the mass grave in Pucayacu. However, before the case could come to trial, Artaza was the "victim" of a staged kidnapping. Subsequently, with his whereabouts unknown, Artaza filed a petition for annulment with the Tribunal of Constitutional Guarantees, requesting that jurisdiction be transferred to a military tribunal; the petition was granted, effectively foreclosing the case against Artaza. ${ }^{62}$

In brief, the Peruvian judicial system represents a patent case of institutional inefficacy, as it has systematically failed to enforce constitutional safeguards for basic human rights or sanction military personnel who bear culpability for violations. The Office of the Public Ministry, charged with acting as an ombudsman or defender of individual rights even during a state of emergency, has been only marginally more effective. The Public Ministry is an autonomous monitoring institution which receives complaints about human rights violations, conducts investigations, and is empowered to press charges against military or policy officials. However, when Belaúnde declared a state of emergency in the southern highlands, public prosecutors who were supposed to investigate human rights violations were not informed of detentions and were denied access to military headquarters and contact with prisoners. Indeed, threats led a number of prosecutors to resign their positions in Ayacucho. ${ }^{63}$ Similarly, when Deputy Javier Diez Canseco filed suit against General Clemente Noél (the head of the political-military command in Ayacucho) for human rights violations in 1983, the Public Ministry did little to investigate the charges and quickly closed the case. ${ }^{64}$

Some improvement in the performance of this branch of government occurred in 1987-1988 with the creation of a new position, the Superior Prosecutor-Commissioner for the Investigation of Disappearances. Carlos Escobar Pineda assumed this new post and the responsibility for investigating disappearances in Ayacucho. Escobar had some short-term success in establishing military responsibility for human rights violations and locating individuals who had been reported as disappeared. However, his activities, especially his investigation of a massacre in Cayara in 1988, earned Escobar the enmity of the armed forces and several death threats, including one from the Comando Rodrigo Franco. ${ }^{65}$ In November 1988, Attorney General Hugo

62. Americas Watch, note 22 above, 41.

63. Americas Watch, note 1 above, 148-50.

64. Ibid., 151-52.

65. See Americas Watch, note 22 above, 71-73. 
Denegri Cornejo announced that Escobar's office would be closed-allegedly due to a lack of funds-shortly after Escobar's report on the Cayara massacre recommended that Army General José Valdivia Duenas, the Political-Military Commander of the Ayacucho Emergency Zone, be prosecuted for murder.

Indeed, the investigation of the Cayara massacre, in which at least twenty-nine people were killed, provides revealing insight into the institutional failure of the Public Ministry in Peru. On 13 October 1988, Escobar filed a report which identified General Valdivia as the official responsible for the Cayara massacre. Although Escobar reported that evidence existed to prosecute Valdivia and other officials, the provincial public prosecutor refused to press charges, claiming that it was not possible to individualize responsibility. The case was definitively closed in January 1990, when the public prosecutor filed a resolution denying the existence of a massacre at Cayara. This resolution stated that the persons allegedly murdered had actually fled Cayara due to their involvement with Sendero Luminoso and that the testimonies provided to Escobar by witnesses had been falsified under terrorist threat. ${ }^{66}$ Between June 1988 and September 1989, the nine surviving witnesses of the Cayara massacre were killed or "disappeared" in different incidents involving state security forces. ${ }^{67}$

As such, the failure of the judiciary to establish civilian jurisdiction over human rights violations has been compounded by the inability or unwillingness of the Public Ministry to conduct effective investigations and initiate prosecution. Faced with the impotency of the judiciary and the Public Ministry, members of the Peruvian Congress have tried to fill the void and have made a number of attempts to defend human rights and hold the armed forces accountable for violations. For example, the senate appointed a special commission chaired by Rolando Ames to investigate the 1986 prison revolts and the subsequent massacre carried out by the armed forces. The report issued by the Ames Commission challenged the constitutionality of an executive decree that established military jurisdiction in the prison revolt case, on the grounds that the constitution does not allow military jurisdiction over civilians and empowers only the supreme court to make jurisdictional decisions. In its report, the Ames Commission included a transcript of a 16 June 1986 cabinet meeting in which President García stated:

The President expresses his commendation to the Joint Command of the Armed Forces for the efficient compliance with the orders of the government. It is also pointed out that, according to Law 24,150 which regulates states of exception,

66. "Resolucion No. Uno-Noventa," Ministerio Publico, Fiscalia Provincial Mixta de Victor Fajando, Ayacucho, 23 Jan. 1990.

67. U.S. Department of State, Country Report on Human Rights Practices for 1989: Peru (Washington: Feb. 1990), 710-11. See also Inter-Church Committee on Human Rights in Latin America, note 37 above, 22. 
jurisdiction in this matter lies with military courts; therefore, it was decided that civilian judges would not be allowed to enter the prisons nor the nearby premises, starting that same afternoon; the prisons are declared Restricted Military Zones, and access to civilians is thus prohibited. ${ }^{68}$

The Ames Commission also recommended that congress invoke a constitutional proceeding under Article 183 that would suspend certain high government officials, including García and his cabinet members, and subject them to criminal charges and judicial action similar to the impeachment process in the United States. However, the APRA majority in congress watered down these recommendations and limited judicial proceedings to military and police officials, under military jurisdiction. ${ }^{69}$ In December 1989, the military tribunal found two police officers responsible for the deaths of 124 inmates at the Lurigancho prison and sentenced them to prison terms. However, the remaining seventy-six persons under trial were absolved by the military tribunal, including Army General Jorge Rabanal Portilla, the military officer in charge of anti-subversive operations at the prison, and all other officials of the armed forces.

As such, the Ames Commission played a significant role in investigating the prison massacre, establishing culpability, and informing the public of the decisionmaking process which led to the tragic events in June 1986. However, it was not able to induce assertive behavior on behalf of human rights from the ruling party in congress or the military justice system.

In contrast to the Ames Commission, which made a conscientious effort to clarify events surrounding the prison massacre, other congressional commissions-such as the APRA-controlled commission that investigated the massacre in Cayara - have served primarily to obstruct and obfuscate serious investigations. Americas Watch concludes that the Cayara Commission headed by APRA Senator Carlos Melgar directed its investigatory zeal "toward covering up the facts, protecting the possible culprits ... and obstructing the independent investigation carried out by the Prosecutor." ${ }^{\prime 70}$ The official report filed in May 1989 by the APRA majority of the Melgar Commission denied that the armed forces had committed offenses at Cayara. The report recommended that legal action be taken against Special Prosecutor Escobar for usurping the investigative authority of the provincial public prosecutor and claimed that the allegations against General Valdivia were part of a subversive campaign to undermine his command in the Ayacucho emergency zone. ${ }^{71}$

There have also been efforts in congress to pass legislation that would give civilian courts legal jurisdiction over military personnel accused of

68. Cited in Americas Watch, note 22 above, 64.

69. Ibid., 61-65.

70. Ibid., 67.

71. Amnesty International, note 35 above, 32-33. 
serious crimes, including genocide, enforced disappearance, the denial of information about detainees, extrajudicial execution, and sexual violations. Although a draft law establishing civilian jurisdiction and legal sanctions for such crimes was approved by the senate in 1986, it was effectively blocked in the lower house of congress and prevented from being scheduled for debate. Likewise, a proposed amendment to Law 24,150 that would enhance civilian authority in emergency zones has been bottled up in congress. Therefore, despite the efforts of opposition legislators, congress has failed to manifest the political will required to establish a more rigorous legislative foundation for the protection of human rights.

\section{CONCLUSION}

The gravity of the human rights situation under Peruvian democracy is revealing in a number of important respects. The Peruvian case demonstrates that "national security doctrines" that sacrifice human rights on the altar of internal security are not the exclusive property of military regimes. This is perhaps not surprising in nations like El Salvador and Guatemala, where elected governments replaced highly repressive military regimes in the midst of intensive counterinsurgency campaigns and were from the outset severely constrained by pervasive military power. Indeed, such regime changes may be an integral component of counterinsurgency strategies, since a process of "democratization," even when restricted, may facilitate recourse to foreign assistance, allow the armed forces to concentrate on security affairs, and dissipate or fragment the energies of opposition movements. In contrast, the democratic regime in Peru was not born with such debilitating "birth defects 172 and was not initially associated with counterinsurgency; nevertheless, it adopted key features of the national security ideology and yielded to military prerogatives when confronted with a guerrilla insurgency.

As such, the Peruvian case has considerable relevance for other nations that have undergone democratic transitions or are faced with guerrilla insurgencies. In particular, it illustrates the variety of means by which democratic procedural and institutional mechanisms which are designed to safeguard human rights may fail or break down. In Peru, these institutional failures include the abdication of civilian political and administrative authority in the emergency zones; the transfer of legal jurisdiction from civilian to military courts; juridical impotence in the enforcement of existing constitutional rights and the prosecution of military personnel for abuses of

72. The term is borrowed from Terry Lynn Karl, who uses it, in a different context, to refer to the constraints imposed upon newly established democratic regimes by their foundational "pacts"; see her "Petroleum and Political Pacts: The Transition to Democracy in Venezuela," Latin American Research Review 22, 1 (1987): 63-94. 
power; the unwillingness of congress to legislate stricter legal protection or sanction government officials for complicity in human rights abuses; the inability of the public ministry to investigate violations thoroughly and press for effective prosecution; and the failure of the military hierarchy to enforce human rights standards in the counterinsurgency campaign.

The failure of Peru's democratic institutions to ensure respect for human rights has thus been multifaceted and multicausal. In short, this is not a simple case of military encroachment upon civilian authority; Peru's civilian leaders have abdicated some of their administrative and juridical authority, but their political responsibility for the course of events remains undiminished. Having launched a counterinsurgency campaign behind a facade of democratic institutions, the Belaúnde and García administrations failed to ensure that constitutional principles and legal safeguards would remain in force. Perhaps most important, these administrations did little to develop alternative approaches to counterinsurgency that would be more compatible with democratic procedures and human rights norms. ${ }^{73}$ Neither of these civilian administrations demonstrated a capacity to utilize democratic norms, procedures, and institutions as instruments to mobilize citizen support and participation in the effort to contain a guerrilla insurgency that has itself engaged in massive and systematic attacks against civilian noncombatants.

Indeed, the scale of violence carried out by Sendero Luminoso has promoted concern within the human rights community that the conventional focus on governmental abuses is inadequate to deal with the complexities and idiosyncracies of the Peruvian case. ${ }^{74}$ Attacks on the civilian population by Sendero have not only led to arguments that human rights standards should be applied to insurgent movements as well as to states, but also to efforts to explore how civil society and democratic institutions can be fortified for self defense. Inarguably, the role of civil society in the pacification of Peru is controversial, especially when it touches on the sensitive issue of civil defense patrols and the arming of peasant communities. ${ }^{75}$ Nevertheless, these issues have acquired considerable salience in the debate over pacification, as the administration of newly elected President Alberto Fujimori

73. This is a topic which has received attention within political and academic circles, especially among Peruvians who believe it is necessary to confront the Sendero Luminoso insurgency, but do not want to undermine democratic principles or institutions in the process. See, for example, the discussion about the differences between French and British counterinsurgency doctrines in Gustavo Goritti, "Insurgencia y Democracia," Debate 12, 59 (MarchApril 1990): 49-51; see also the report of the Comision Especial del Senado Sobre Las Causas de la Violencia y Alternativas de Pacificacion en el Peru, Violencia y Pacificacion (Lima: Desco and the Comision Andina de Juristas, 1989), 309-12.

74. See Michael Shifter, "Derechos Humanos: Un Nuevo Enfoque," Debate 12, 59 (MarchApril 1990): $43-49$.

75. The issues involved in this debate are discussed in Instituto de Defensa Legal, note 31 above, 124-33. 
assumes office in the midst of an ever-expanding insurgency and a diminishing state capacity to defend basic rights or perform essential functions.

Regrettably, human rights concerns received relatively little attention in the 1990 presidential and congressional campaigns, which were dominated by the economic crisis and the "terrorism" issue. ${ }^{76}$ Consequently, an opportunity was lost to utilize democratic procedures to enrich the debate over human rights and the mechanisms for their protection. One of the ironies of the Peruvian case is that the nation's democratic regime-in contrast to many dictatorships-offers the potential advantage of providing political space for an independent press, opposition political parties, and human rights monitoring organizations that seek to utilize democratic institutional channels to modify state policies and keep the debate over human rights alive. However, as this study suggests, these institutions in civil society have found the Peruvian state decidedly unresponsive to human rights concerns. As such, one of the great challenges in the future will be to activate the corrective and adaptive mechanisms of political democracy to promote both policy change and institutional reform within the Peruvian state, thus enabling the human rights safeguards enshrined in the nation's constitutional framework to be implemented more effectively.

76. The presidential candidate of the United Left, Henry Pease, raised human rights concerns most explicitly by calling for the abolishment of the political-military commands and the reassertion of civilian political authority in the emergency zones. In contrast, the two leading candidates - the independent Alberto Fujimori, who was elected, and conservative novelist Mario Vargas Llosa-discussed the terrorism-insurgency problem without fully developing the implications for human rights. Whereas Fujimori emphasized an "integrated" counterinsurgency strategy that would address the social and economic problems underpinning the insurgency, Vargas Llosa stressed the need to strengthen the state's military response and arm civil defense patrols. 